\title{
CUTICLES FROM PENNSYLVANAN MARATTIALEAN FERN "PECOPTERIS" POLYPODIOIDES (C. PRESL IN STERNBERG) NĚMEJC FROM PILSEN BASIN (CZECH REPUBLIC) AND SYDNEY COALFIELD (CANADA)
}

\author{
Josef Pšenička1 ${ }^{1}$ \& Erwin L. Zodrow ${ }^{2}$ \\ ${ }^{1}$ Centre of Palaeobiodiversity, West Bohemian Museum in Pilsen, Kopeckého sady 2, 30100 Pilsen, Czech Republic; \\ jpsenicka@zcm.cz \\ 2 Palaeobiology Laboratory, and Curator, Cape Breton University, Sydney, Nova Scotia, B1P 6L2, Canada, \\ zzodrovii@gmail.com
}

\begin{abstract}
Pennsylvanian fossil-fern cuticles are notoriously difficult to extract, little can be found in the palaeobotanical literature, yet they can supply significant taxonomic/systematic, phytostratigragphic, and palaeoenvironment information. This is demonstrated for cuticles from "Pecopteris" polypodioides of the coal basins in the Czech Republic and Canada. "Pecopteris" polypodioides is a marattialean tree fern which was part of the peat-forming flora, growing in a wet environment. Due to this fact, cuticles are generally very thin, and we assume that their major function was to reduce the ability of fungal spores to germinate and bacterial to grow, thereby reducing the possibility of these agents to cause disease. The secondary function was to be a major barrier to water loss and reducing the wettability of pinnules.
\end{abstract}

Key words: Pennslyvanian, Pecopteris, cuticles, Czech Republic-Canadian basins.

\section{INTRODUCTION}

Pecopterids sensu lato played an important role for biostratigraphy as well as for palaeoecology during the Pensylannian age. They were systematically studied by several authors (e.g. Bell, 1938; Němejc, 1940; Corsin, 1951; Dalinval, 1960; Laveine, 1969, 1970; Pšenička, 2005). Nevertheless, their clear classification has still never been satisfactorily resolved. One problem with the classification resides in the different preservation states of the individual specimens, which not only relate to permineralized and compression. Of particular concern is also the classification of pecopterids that fossilized as compressions. In many cases only "artificial" outlines of pinnules are visible, which do not correspond with the real pinnule margin because the pinnule lamina is often curved, and venation is not visible especially when pinnules are covered by reproductive organs. An added problem is that only smaller and different parts of the large marattialean fronds that could reach two meters or more were preserved.

However, an important taxonomic methodology in modern palaeobotanical investigations is cuticular analysis, or the study of epidermal structures imprinted on the plant-fossil cuticles. Florin (1929) used it as part of his taxonomic work with Carboniferous conifers, and Barthel (1962) pioneered cuticular analysis in a systematic manner for pteridosperms, which was used as a basis by Cleal \& Zodrow (1989) for classifying European and Canadian pteridosperms.

However, our knowledge about cuticles of Palaeozoic ferns is still very poor, although the simple fern epidermis can potentially provide important palaeobiological information. This is mainly because the epidermis in Palaeozoic ferns is weakly cutinised, and only small fragments of cuticle can usually be obtained. This work shows that it is possible to obtain cuticles of ferns for comparison with living ferns, and other plant fossils.

This study focused on cuticular and epidermal structures of "Pecopteris" polypodioides (C. Presl in Sternberg) Němejc that were originally described by C. Presl in Sternberg (1820) as Goeppertia polypodioides from the Czech Republic. The holotype is preserved as impression and consists of an extremely small distal sterile penultimate pinna without any coaly material. A clear concept of this 
species is still not available, hence this species is often misinterpreted as Pecopteris vestita esquereux, Pecopteris abbreviata Lesquereux, Pecopteris (Asterotheca) oreopteridia Brongniart, Pecopteris crenulata Brongniart or P.miltonii (Artis) Brongniart. Based on an unclear species concept, we used quotation marks in the generic name. Pšenička (2005) mentioned this species not only from European localities but also from the Late Pennsylvanian Sydney Coalfield (Canada), based on identical morpohological characters of sterile pinnae/pinnules/ venation.

This paper focuses on the epidermal structures of this species based on one specimen from the Pilsen Basin (Czech Republic), and the other from Sydney Coalfield (Canada). Systematic clarification of this species is not the scope of this study and will be done in a future study.

\section{MATERIAL}

The Canadian specimen (980GF-243) originated from the Lloyd Cove Seam, lower Kasimovian (Cantabrian) (Zodrow, 1985, Text-fig. 1 and 2) and the Czech specimen (F6099) from Tlučná locality Krimich II Mine, Kladno Formation, Nýřany Mem- ber, upper Moscovian (upper Asturian) (Opluštil et al. 2016), (Figure 1A and B). Both specimens are preserved in grey mudstone. The specimens are stored in the Cape Breton University in Sydney, and in the Centre of Palaeobiodiversity, West Bohemian Museum in Pilsen, respectively.

\section{METHOD}

Pinnules were freed from the rock matrix using 35 per cent hydrofluoric acid for 24 hours. Subsequently, they were macerated in Schulze's solution (saturated solution of potassium chlorate in nitric acid) for $10-30$, minutes depending on the degree of coalification, washed in distilled water, then treated with 10 per cent potassium hydroxide to remove oxidation products, and washed again in distilled water. Cuticles were mounted in glycerinejelly slides and observed under Nomarski phasecontrast illumination (biological microscope OLYMPUS BX 51), where they showed clear epidermal or sporangial structures. Some pinnules were also observed under a binocular microscope OLYMPUS SZX12, after treatment in Schulze's solution only, which enabled observing specifically pinnule venation or trichomes restricted to pinnules.

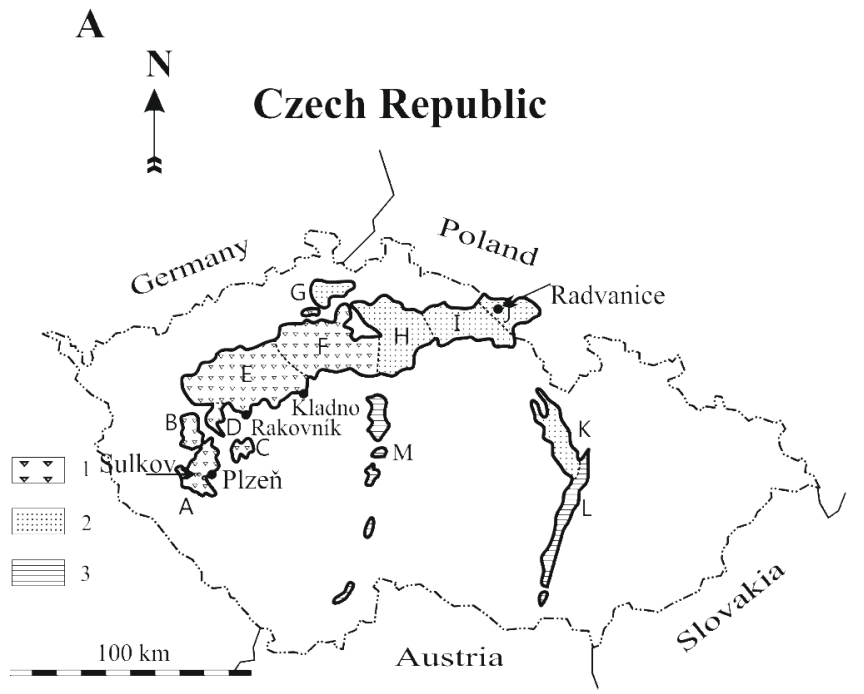

B

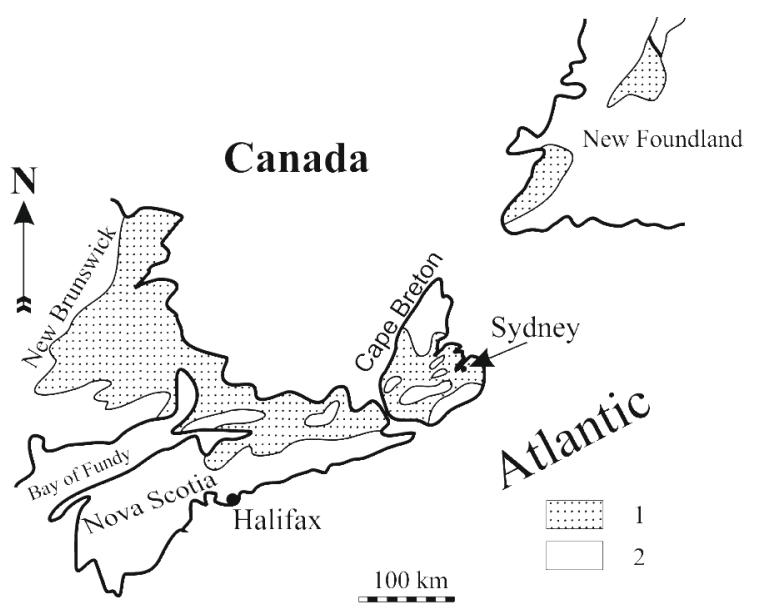

Figure 1. A) Permo-Carboniferous regions and basins in the Czech Republic (Pešek 1994 supplemented by the authors). 1 - Central and Western Bohemian Upper Palaeozoic basins: Western Bohemian District: A - Plzeñ Basin, B - Manětín Basin, C - Radnice Basin, D - Žihle Basin; Central Bohemian District: E - Kladno-Rakouník Basin, F - Mšeno-Roudnice Basin; 2 - Lugicum Upper Palaeozoic Basins: G - Česká Kamenice Basin, H - Mnichovo Hradiště Basin, I - Krkonoše Piedmont Basin, J - Lower Silesian Basin, K-Orlice, 3 - Furrows: L - Boskovice Graben, M - Blanice Graben; B) Pennsylvanian region in Atlantic Canadian - 1. Pennsylvanian deposits, 2. Pre-Pennsylvanian formations. 
Slides, negatives and digital photos of the cuticles are stored in the Centre of Palaeobiodiversity, West Bohemian Museum.

The terminology for cuticles and epidermal structures follows that by Barthel (1962), Kerp (1991), and Sen \& De (1992).

\section{DESCRIPTION}

Cuticles were obtained only from two specimens of a total of nine that were studied from both basins, and though they were not well-preserved many interesting and important features could be documented.

\section{Specimen F6099: Pilsen Basin}

The specimen shows several fragments of sterile penultimate pinnae (Plate I, Fig. 1). The biggest penultimate pinna preserved is $100 \mathrm{~mm}$ long, and represents the upper part of a penultimate pinna (Plate I, Fig. 2). The penultimate rachis is straight, $2 \mathrm{~mm}$ wide. Ultimate pinnae are up to $35 \mathrm{~mm}$ long and $12 \mathrm{~mm}$ wide with a $0.6 \mathrm{~mm}$ wide rachis. Pinnules alternate, slightly united to each other in their basal part, $4 \mathrm{~mm}$ long and $2.5 \mathrm{~mm}$ wide, with an obtuse apex (Plate II, Fig. 2). The marked midvein is curved in the basal part and lateral veins are once dichotomized.

\section{Cuticle}

Adaxial cuticle is thin, differentiated in costal (Plate II, Fig. 8) and intercostals fields (Plate II, Fig. 6) (Figure 2A). Costal cells are elongate, tetragonal up to $180 \mu \mathrm{m}$ long and $8 \mu \mathrm{m}$ wide, and intercostals cells are irregular in shape, polygonal (tetragonal), 40-80 $\mu \mathrm{m}$ long and 20-30 $\mu \mathrm{m}$ wide.
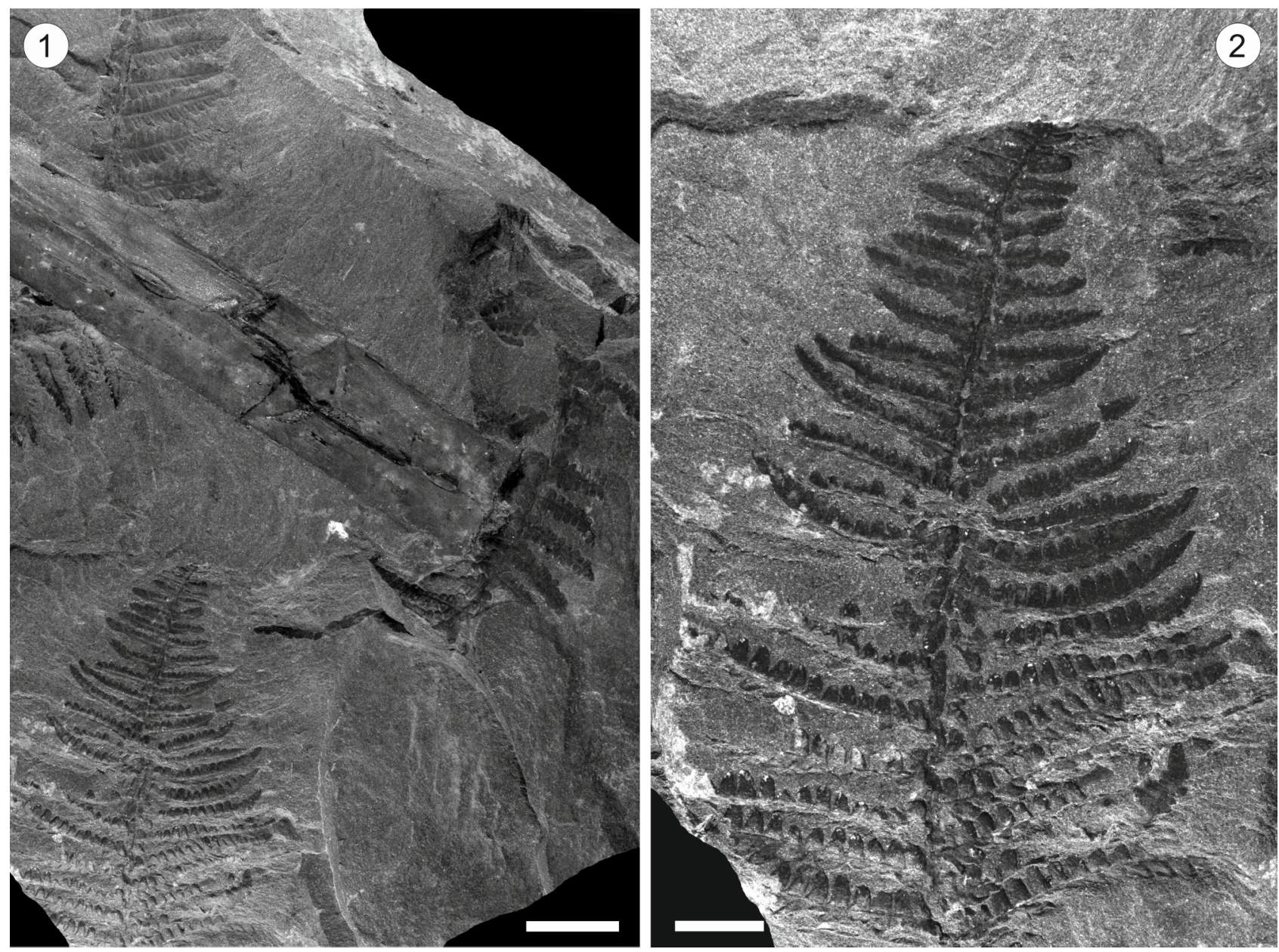

Plate I, "Pecopteris” polypodioides from Tlučná locality - Krimich II Mine; specimen F6099; 1) Many fragments of penultimate pinnae, scale bar $20 \mathrm{~mm}$; 2) Detail of the largest penultimate pinnae from specimen, scale bar $10 \mathrm{~mm}$. 


\section{Plate II}
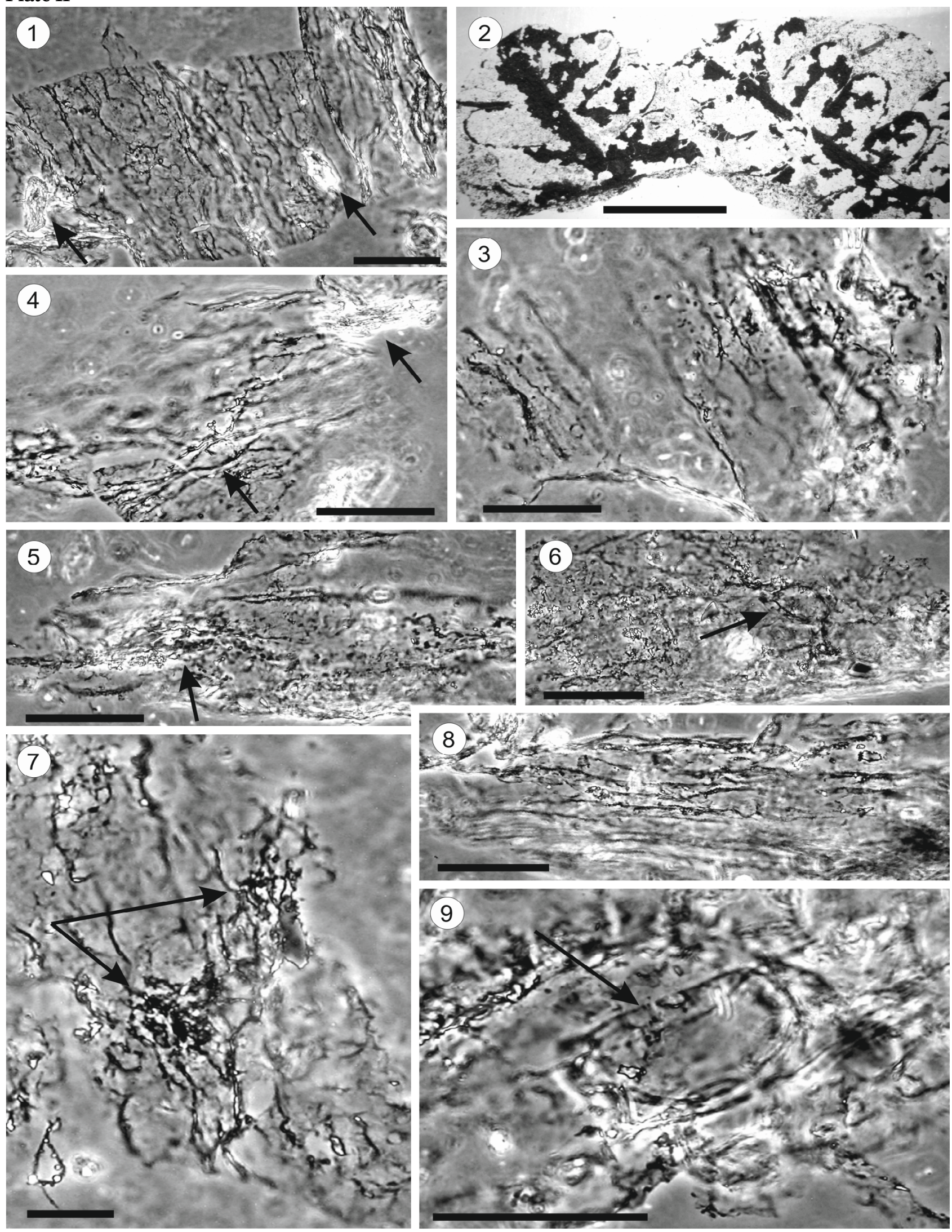
Anticlinal walls are more or less straight. Trichomic bases are $15 \mu \mathrm{m}$ in diameter (Plate II, Fig. 6 arrowed).

Abaxial cuticle is thin, differentiated in costal and intercostal fields. The costal cells are elongate, tetragonal up to $150 \mu \mathrm{m}$ long and $8 \mu \mathrm{m}$ wide, and intercostal cells are irregular, polygonal (tetragonal), 40-80 $\mu \mathrm{m}$ long and 20-30 $\mu \mathrm{m}$ wide. Anticlinal walls are more or less straight. Stomata occur only in the intercostal fields, where they are poorly preserved, cyclocytic (Figure 2C; Plate II, Figs 1, 3- 5, 7 all arrowed), $35 \mu \mathrm{m}$ long and $18 \mu \mathrm{m}$ wide, and irregularly scattered on abaxial cuticles. They are more or less oriented parallel to the lateral veins. The stomatal density is c. 68 per $\mathrm{mm}^{2}$. Glandular trichomes are $30-45 \mu \mathrm{m}$ long and $24 \mu \mathrm{m}$ wide (Figure 2B; Plate II, Fig. 9 arrowed).

\section{Specimen 980GF-243: Sydney Coalfield}

The specimen shows two middle parts of sterile penultimate pinnae (Plate III, Fig. 1) one of which is more than $150 \mathrm{~mm}$ long and $70 \mathrm{~mm}$ wide, and the rachis is straight and $2 \mathrm{~mm}$ wide. Ultimate pinnae are $30-35 \mathrm{~mm}$ long and $10-14 \mathrm{~mm}$ wide with a straight ultimate rachis $0.8-1 \mathrm{~mm}$ wide (Plate III, Fig. 2). Pinnules alternate, are oblong, with blunt rounded apices, more or less convex, slightly oblique, very slightly united to each other in basal part, $4-5 \mathrm{~mm}$ long, and $2-2.5 \mathrm{~mm}$ wide (Plate III, Figs 2, 3). The venation is clear and distinct with a straight midvein, markedly curved at the base, extending to the apex, and dividing into two veins at the apical part that divided once again (Figure 3A; Plate III, Fig. 3), and correspond to the pinnule pattern of "Pecopteris" polypodioides holotype, stored in the National Museum, Prague, Czech Republic under the number E161a (Figure 3B). Lateral veins are prominent, departing from the midvein, once dividing in their lower part and sometimes divided once again (Plate III, Fig. 3A).

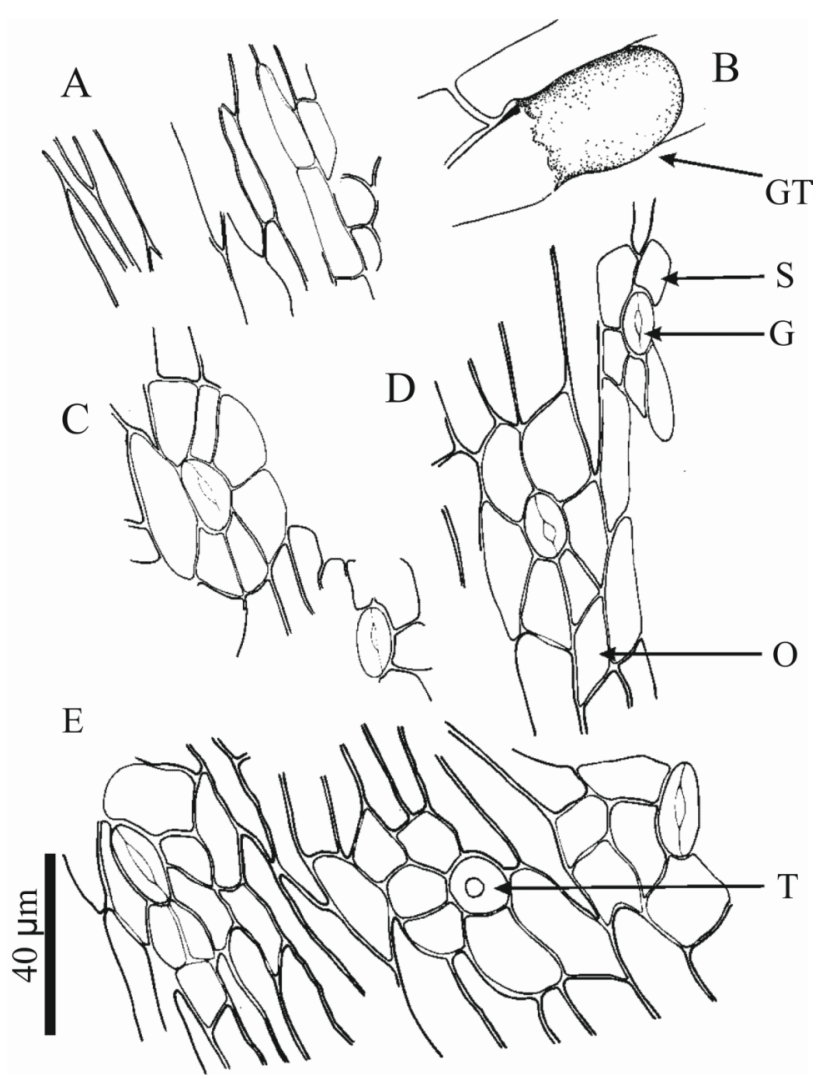

Figure 2. Camera lucida drawing of a cuticle from the slides of "Pecopteris" polypodioides from Tlučná locality (specimen F6099); A) Adaxial cuticle differentiated into costal (elongate tetragonal cells) and intercostal fields (polygonal cells) - photograph Plate II, Fig. 3; B) Glandular trichome (GT) on the abaxial side - photograph Plate II, Fig. 9; C) Cyclocytic stomata on the abaxial side ; D) Cyclocytic stomata on the abaxial side with ordinary cells $(O)$, subsidiary cells $(S)$, and guard cells $(G)$ - photograph Plate II, Fig. 7; E) Stomatal and trichomic base (T) on abaxial side.

\section{Cuticle}

Adaxial cuticle is thin, differentiated in costal (Plate III, Fig. 4) and intercostals fields (Plate III, Fig. 5). Costal cells are elongate, tetragonal up to $170 \mu \mathrm{m}$ long and $8-10 \mu \mathrm{m}$ wide (Plate III, Fig. 4)

Plate II, "Pecopteris" polypodioides from Tlučná locality - Krimich II Mine; specimen F6099; all photographs - phase illumination; 1) Abaxial cuticle with costal and intercostal fields. Faintly visible are outlines of cyclocytic stomata (arrowed) in the intercostal fields, scale bar $50 \mu \mathrm{m} ; 2$ ) Fragment of ultimate pinnae after HF treatment mounted in collodion film, scale bar 5 $\mathrm{mm}$; 3) Adaxial cuticle differentiated into costal (elongate tetragonal cells) and intercostal field (polygonal cells), scale bar 50 $\mu \mathrm{m}$; 4) Abaxial cuticle with two cyclocytic stomata (arrowed), scale bar $50 \mu \mathrm{m}$; 5) Not well the preserved stomata on the abaxial side, scale bar $50 \mu \mathrm{m}$; 6) Adaxial cuticle with trichomic base (arrowed), scale bar $50 \mu \mathrm{m}$; 7) Abaxial cuticle showing faint outlines of cyclocytic stomata (arrowed) in the intercostal field, scale bar $50 \mu \mathrm{m}$; 8) Adaxial cuticle, costal field, defined by more or less elongate, tetragonal cells, scale bar $100 \mu \mathrm{m}$; 9) Detail of glandular trichome on the abaxial side, scale bar $50 \mu \mathrm{m}$. 


\section{Plate III}

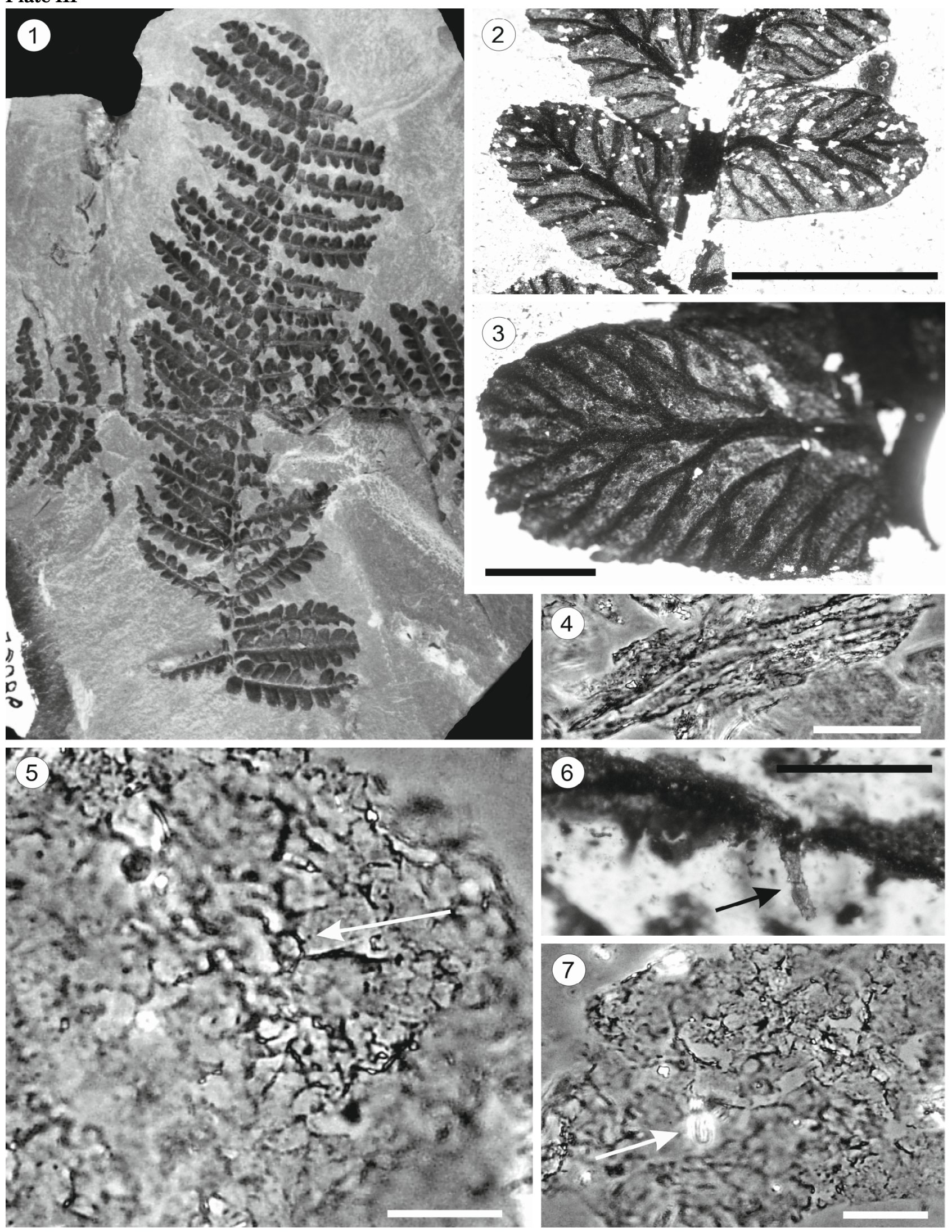


Table 1. Measurements of cuticle parameters from both specimens; CO - costal cells, ICO - intercostal cells, L - long, $\mathrm{W}$ - wide, $\mathrm{Pr}$ - presence, $\mathrm{T}$ - trichrome; all measurements are in $\mu \mathrm{m}$.

\begin{tabular}{|c|c|c|c|c|c|c|c|c|c|c|c|c|c|c|c|c|}
\hline \multirow{4}{*}{ specimen } & \multicolumn{6}{|c|}{ adaxial cuticle } & \multicolumn{10}{|c|}{ abaxial cuticle } \\
\hline & \multicolumn{4}{|c|}{ cells } & \multicolumn{2}{|r|}{$\mathrm{T}$} & \multicolumn{4}{|c|}{ cells } & \multicolumn{2}{|r|}{$\mathrm{T}$} & \multicolumn{4}{|c|}{ stomata } \\
\hline & \multicolumn{2}{|c|}{$\mathrm{CO}$} & \multicolumn{2}{|c|}{ ICO } & \multirow{2}{*}{$\operatorname{Pr}$} & \multirow{2}{*}{ type } & \multicolumn{2}{|c|}{$\mathrm{CO}$} & \multicolumn{2}{|c|}{ ICO } & \multirow{2}{*}{$\operatorname{Pr}$} & \multirow{2}{*}{ type } & \multirow{2}{*}{ type } & \multirow{2}{*}{ st. density } & \multirow{2}{*}{ W } & \multirow{2}{*}{$\mathrm{L}$} \\
\hline & $\mathrm{L}$ & W & $\mathrm{L}$ & $\mathrm{W}$ & & & $\mathrm{L}$ & W & $\mathrm{L}$ & $\mathrm{W}$ & & & & & & \\
\hline F6099 & 180 & 8 & $40-80$ & $20-30$ & yes & ? & 150 & 8 & $40-80$ & $20-30$ & yes & glandular & cyclocytic & 68 per $\mathrm{mm}^{2}$ & 18 & 35 \\
\hline 980GF-243 & 170 & $8-10$ & 70-70 & $30-60$ & yes & $\begin{array}{l}\text { uniseriate, } \\
\text { multicellular }\end{array}$ & ? & $?$ & $40-80$ & $30-70$ & ? & ? & cyclocytic & 62 per $\mathrm{mm}^{2}$ & 15 & 30 \\
\hline
\end{tabular}
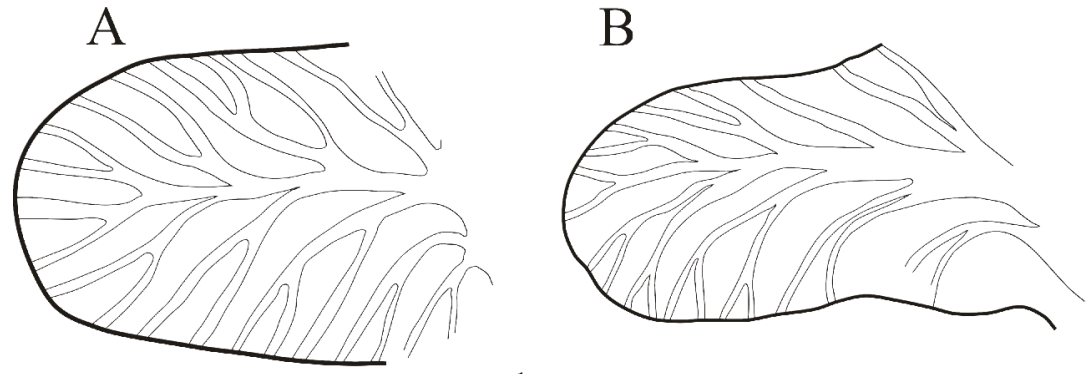

$1 \mathrm{~mm}$

Figure 3. Comparison of venation of "Pecopteris" polypodioides between 980GF-243 (A) from Sydney Coalfiel, Canada and holotype (B) from Plasy locality, Czech Republic, No. E161 stored in National Museum, Prague, Czech Republic).
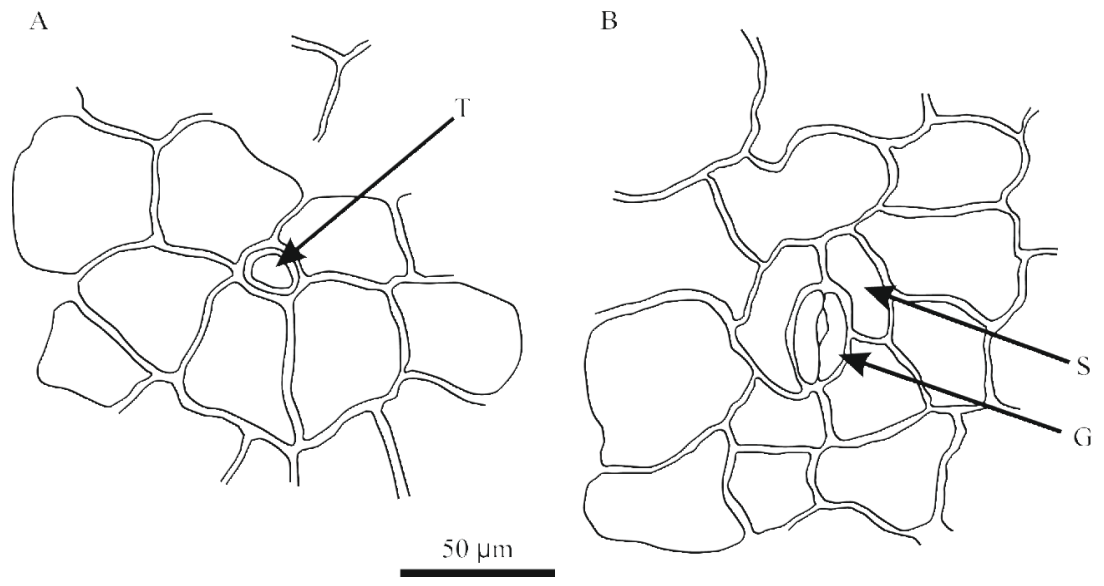

Figure 4. Camera lucida drawing of a cuticle from the slides of "Pecopteris" polypodioides from the Sydney locality; A) Adaxial cuticle with trichomic base (T); $B$ ) Cyclocytic stoma on the abaxial side with subsidiary cells (S) and guard cells $(G)$. and intercostal cells are irregular in shape, polygonal, 40-70 $\mu \mathrm{m}$ long and $30-60 \mu \mathrm{m}$ wide (Plate III, Fig. 5). Anticlinal walls are more or less straight. Trichomic bases are $15 \mu \mathrm{m}$ in diameter (Figure 4A; Plate III, Fig. 5 arrowed). Trichomes themselves are up to $90 \mu \mathrm{m}$ long, uniseriate, multicellular and scattered in the costal (Plate III, Fig. 6 arrowed) and intercostal fields.

Abaxial cuticle is extraordinarily thin, and probably differentiated in costal and intercostal fields. The intercostal cells are irregular, polygonal, 40-80 $\mu \mathrm{m}$ long and 30-70 $\mu \mathrm{m}$ wide. Anticlinal walls are more or less straight. Stomata occur in the intercostal fields, and are poorly preserved, cyclocytic (Figure 4B; Plate III, Fig. 7 arrowed) $30 \mu \mathrm{m}$ long and $15 \mu \mathrm{m}$ wide, irregularly scattered on the abaxial cuticle. The stomatal density is ca. 62 per $\mathrm{mm}^{2}$.

Plate III, "Pecopteris" polypodioides from the Sydny locality; specimen 980GF-243; photographs of cuticles - Nomarski phasecontrast illumination; 1) Two incomplete sterile penultimate pinnae, scale bar $20 \mathrm{~mm}$; 2) Deatil of the middle part of an ultimate pinna with attached pinnules, scale bar $5 \mathrm{~mm}$; 3) Detail of pinnule venation. Small and short dark lines represent trichomes on pinnule lamina (arrowed), scale bar $1 \mathrm{~mm}$;) Adaxial cuticle with elongated tetragonal cells in costal fields, scale bar $50 \mu \mathrm{m}$; 5) Adaxial cuticle with trichomic bases (arrowed) in the intercostal field, scale bar $50 \mu \mathrm{m}$; 6) Adaxial cuticle with a uniseriate, multicellular trichome (arrowed) in a costal field, scale bar $50 \mu \mathrm{m}$; 7) Poorly preserved abaxial cuticle with cyclocytic stomata, scale bar $50 \mu \mathrm{m}$. 


\section{DISCUSSION}

\section{Taxonomy}

"Pecopteris" polypodioides represents a common pinnule form probably originating from Psaronius Cotta tree ferns established by C. Presl in Sternberg (1820) as Goeppertia polypodioides C. Presl in Sternberg. Nevertheless, the holotype is very small and represents distal parts of a sterile penultimate pinna. Since it originated from the Nýřany Member of Kladno Formation, similar pinnule types from there were later classified as "Pecopteris" polypodioides, especially from Czech localities (e.g Němejc 1940). Nevertheless, some authors, due to the small holotype, ignored this species and described similar pinnules under different names as Pecopteris vestita Lesquereux, Pecopteris abbreviata Lesquereux, Pecopteris (Asterotheca) oreopteridia Brongniart, Pecopteris crenulata Brongniart, P.miltonii (Artis) Brongniart, and others. Pšenička (2005) tried to clarify the concept of this species by proposing a new specific diagnosis, and he also assigned to this species several fertile specimens with reproductive organs grouped as synangia typical reproductive organs of marattialean ferns. According to the new concept of Pennsylvanian marattialean genera published by Cleal (2015), "Pecopteris" polypodioides potentially belongs to Lobatopteris auct. (non Wagner) Cleal. Geographic distribution of "Pecopteris" polypodioides was limited at Europen localities. Pšenička (2005) firstly pointed that this species also occurs outside of Europe - in the Sydney Coalfield, Canada. The comparison was made based on details from Czech Republic specimens (including the holotype) and the rich collection from Sydney Coalfield. Species occur in the upper Moscovian (Asturian/Cantabrian) deposits in the both coalfields. The Canadian species is similar to Lobatopteris vestita which became a widely-quoted species in late Asturian and Cantabrian floras across Euramerica. Nevertheless, a clear concept of Lobatopteris vestita is still outstanding, as is mentioned in Pšenička et al. (2009, p. 140).

Therefore, it will be necessary to revise this species in the future using additional larger specimens from the type locality which were stored in National Museum (Czech Republic), and comparing morphologies from both coalfields (Sydney and Pilsen basins).

\section{Habitat}

The 2-5 m high Psaronius tree ferns were an integral part of low-tree storey (e.g. Opluštil et al. 2009a,b, 2014), and inhabited areas between river arms and temporary lakes, dead channels or swamps in the Pilsen Basin (intermountain basin, Nýřany Member) (Pešek, 1994). The Sydney Basin was part of a fluviolacutrine setting on a coastal plain, subject to sea-level changes and cyclothem developments with slowly developing coal swamps. The Lloyd Cove Seam section fits this scenario with its rich pecopterid flora as under storey of cordaitean stands (Zodrow, 1990; Gibling \& Wightman, 1994; Pascuccei et al. 2000). Both basins belong to the Euramerican floras situated in mainly wet tropical latitude (Hilton \& Cleal, 2007). It means an environment with plenty of water and moisture so that protection against drying has not had to be so strongly developed. This would explain the thin cuticles of "Pecopteris" polypodioides, but not to the exclusion of other factors.

\section{Cuticles}

Generally, the cuticles of "Pecopteris" polypodioides are often very poorly preserved, which makes it difficult to obtain workable specimens for microscopical analysis. Yet, as it is demonstrated, it is possible to extract cuticles, and derive important information relating to both ecology, taxonomy, and phytochemical understanding.

Long-chain lipid compounds as aliphatic hydrocarbon chains are part of the insoluble cutin/cutan that formed a protective coating on the epidermis that as the fossil cuticle constituted a major barrier to water loss from the surface of the plant (Evert, 2007). As far as the cuticle of "Pecopteris" polypodioides is concerned, it is relatively poor in aliphatics, which nevertheless does not detract from its cuticular functions (Pšenička et al. 2005).

Generally, we assume that one of the major functions of cuticles was to reduce the ability of fungal spores to germinate and of bacteria to grow in a wet environment, thereby reducing the possibility of these agents to cause disease. The secondary function involved a major barrier to water loss and reducing the wettability of pinnules.

In terms of biomechanics, Niklas \& Paolillo (1997) mentioned that cuticles together with epidermal cells provide mechanical support and add stiffness to the pinnules. This implies that even 
thin and sterile cuticles in pinnules are better able to hold its planar positions for effective photosynthesis, similarly for pinnae or fronds. On the other hand, the rolled down margins of fertile pinnules provide protection for synangia.

Pinnules bear trichomes on adaxial surfaces, where in many cases trichomic bases furnished the only evidence. Due to small cuticular fragments, it is often impossible to say if trichomes were lost before burial in sediments, during taphonomic processes, or maceration in the laboratory. According to Barthel (1962) or Cleal \& Laveine, (1988), some pteridosperms probably actively abscised the hairs rather than losing them through taphonomic damage. Trichomes have various functions, most of them still unknown, but assumed is that their presence played an important role primarily in plants growing in arid habitats to reduce the transpiration rate. Moreover, Cleal \& Shute (2012) stated that the main function of the pinnule trichomes in pteridosperms was to protect the young frond from herbivory and play a protective role against UV-B radiation damage (Evert, 2007). Assuming a wet habitat for this plant, the presence of trichromes probably represent the protective remains from young fronds.

Pšenička (2005) described cuticles from several Pennsylvanian marattialean fern species, but glandular trichomes are known only from "Pecopteris" polypodioides from the Pilsen Basin. This epicuticular feature is a potential classification parameter for this species. We also assume that they were protective against herbivory (see Krings et al. 2003), which among other factors may explain the absence of herbivory.

Both specimens of "Pecopteris" polypodioides showed differentiated cuticles in the costal and intercostal fields of both adaxial and abaxial pinnule surfaces. The size of cells of both specimens are almost identical (Table 1). Stomatal apparatuses are also well-nigh the same size (Table 1), occurred strictly in intercostal fields on the abaxial side, and are categorized as being cyclocytic (surrounding cells oriented themselves in a ring). These nearly identical cuticular characters, in fact, imply conspecifity, which correspond with macroscopically observation.

According to Sen \& De (1992), the cyclocytic type of stomatal organization is common in extant marattialean ferns, although it also may rarely appear in Platycerioideae, Microsorioideae or Oleandroideae. In conjunction with reproductive organs (synangia), it is clearly demonstrated that "Pecopteris" polypodioides is actually a Pennsylvanian member of the marattialean ferns.

Data sets about cuticle of this type of plant from the geological past are still very poor and their mutual comparison is meanwhile impossible. Therefore, we believe that this article may become a basis for similar types of papers.

\section{ACKNOWLEDGEMENTS}

Authors appreciate the financial support received from the Natural Science and Engineering Research Council of Canada, and the American Chemical Society, Petroleum Research Fund \# 37539-AC8.

\section{REFERENCES}

Barthel, M. 1962. Epidermisuntersuchungen an einigen inkohlten Pteridospermenblättern des Oberkarbons und Perms. Geologie11, Beiheft 33, Berlin, 140 pp.

Bell, W.A. 1938. Fossil Flora of Sydney Coalfield, Nova Scotia. Geological Survey of Canada Memoir 215, $334 \mathrm{pp}$.

Cleal, C.J. 2015. The generic taxonomy of Pennsylvanian age marattialean fern frond adpressions. Palaeontographica, Abt. B: Palaeobotany Palaeophytology, 292/1-3, 1-21.

Cleal, C.J., Laveine, J.P. 1988. The juvenile frond of the Middle Carboniferous pteridosperm Paripteris Gothan. Geobios, 21, 245-250.

Cleal, C.J., Shute, C.H. 2012. The systematic and palaeoecological value of foliage anatomy in Late Palaeozoic medullosalean seed-plants. Journal of Systematic Palaeontology, 10/ 4, 765800.

Cleal, C.J., Zodrow, E.L. 1989. Epidermal structure of some medullosan Neuropteris foliage from the middle and upper Carboniferous of Canada and Germany. Palaeontology, 32, 837-882.

Corsin, P. 1951. Bassin houiller de la Sarre et de la Lorraine, I. Flore Fossile 4me Fascicule Pécoptéridiées. Études des Gite Minéraux de la France. $370 \mathrm{pp}$.

Dalinval, A. 1960. Contribution a l'étude des pécoptéridées, Les pecopteris du bassin houiller 
du nord de la France. Theses á la Faculté des Sciences de Lille, France, 222 pp.

Evert, R.F. 2007. Esau's Plant Anatomy, Meristems, Cells, and Tissues of the Plant Body: Their Structure, Function, and Development. Third Edition. Published by John Wiley \& Sons, Inc., Hoboken, New Jersey, 601pp.

Florin, R. 1929. Palaeozoic conifers. Proceedings Of The International Congress Of Plant Sciences - Ithaca 1, 401-411.

Gibling, M., Wightman, W.G. 1994. Palaeovalleys and protozoan assemblages in a Late Carboniferous cyclothem, Sydney Basin, Nova Scotia. Sedimentology 41, 699-719.

Hilton, J., Cleal, C.J. 2007. The relationship between Euramerican and Cathaysian tropical floras in the Late Palaeozoic: Palaeobiogeographical and palaeogeographical implications. EarthScience Reviews, 85, 85-116.

Kerp, J. H. F. 1991. The study of fossil gymnosperms by means of cuticular analysis. Palaios 5, 548569.

Krings, M., Kellog, D.W., Kerp, H., Taylor, T.N. 2003. Trichomes of the seed fern Blanzyopteris praedentata: implications for plant-insect interactions in the Late Carboniferous. Botanical Journal of the Linnean Society 141, 133-149.

Laveine, J.P. 1969. Quelques Pécoptéridiées houilléres á la lumiére de la palynologie. Pollen et Spores, 11, 619-668.

Laveine, J.P. 1970. Quelques Pécoptéridinées houillères a la lumière de la palynologie (II). Implications paléobotaniques et stratigraphiques. Pollen et Spores 12, 235-297.

Němejc, F. 1940. The pecopterides of the coal districts of Bohemia. Sborník Národního Musea v Praze 2 B, 1-28.

Niklas, K.J., Paolillo, D.J. 1997. The role of the epidermis as a stiffening agent in Tulipa (Liliaceae) stems. American Journal of Botany, 84, 735-744.

Opluštil, S., Pšenička, J., Libertín, M., Bashforth, A.R., Šimůnek, Z., Drábkova, J., Dašková, J. 2009a. A Middle Pennsylvanian (Bolsovian) peat-forming forest preserved in situ in volcanic ash of the Whetstone Horizon in the Radnice Basin, Czech Republic. Review of Palaeobotany and Palynology 155, 234-374. DOI 10.1016/ j.revpalbo.2009.03.002
Opluštil, S., Pšenička, J., Libertín, M., Bek, J., Dašková, J., Šimůnek, Z., Drabková, J. 2009b. Composition and structure of an in situ Middle Pennsylvanian peat-forming plant assemblage in volcanic ash, Radnice Basin (Czech Republic). Palaios 24, 726-746. DOI 10.2110/palo.2008. p08-128r

Opluštil, S., Schmitz, M., Cleal, C.J., Martínek, K. 2016. A review of the Middle-Late Pennsylvanian west European regional substages and floral biozones, and their correlation to the Geological Time Scale based on new U-Pb ages. Earth-Science Reviews 154, 301-335.

Pascuccei, V., Gibling, M.R., Williamson, M.A. 2000. Late Palaeozoic to Cenozoic history of the offshore Sydney Basin, Atlantic Canada. Canadian Journal of Earth Sciences 37, 1143-1165.

Pešek, J. 1994. Carboniferous of Central and Western Bohemia (Czech Republic). Czech Geological Survey, Prague, 60 pp.

Pšenička, J. 2005. Taxonomy of Pennsylvanian Permian ferns from coal Basins in the Czech Republic and Canada. 185 pp. Ph.D. thesis, Faculty of Science, Charles University, Prague, Czech Republic.

Pšenička, J., Zodrow, E.L., Mastalerz, M., Bek, J. 2005. Functional groups of fossil marattialeans: Chemtaxonomic implications for Pennsylvanian tree ferns and pteridosphylls. International Journal of Coal Geology 61, 259-280.

Pšenička, J., Bek, J., Cleal, C.J., Wittry, J., Zodrow, E.L. 2009. Description of synangia and spores of the holotype of the Carboniferous fern Lobatopteris miltoni, with taxonomic comments. Review of Palaeobotany and Palynology 155, 133-144.

Sen, U., De, B., 1992. Structure and ontogeny of stomata in ferns. Blumea 37, 239-261.

Sternberg, K.M., 1820. Versuch einer geognostischen botanischen Darstellung der Flora der Vorwelt. - vol I, F. Fleischer, Leipzig, 1-24.

Zodrow, E.L. 1985. Odontopteris Brongniart in the Upper Carboniferous of Canada. Palaeontographica B 196, 79-110.

Zodrow, E.L. 1990. Revision and emendation of Pecopteris arborescens Group, Permo-Carbboniferous. Palaeontographica B 217, 1-49. 